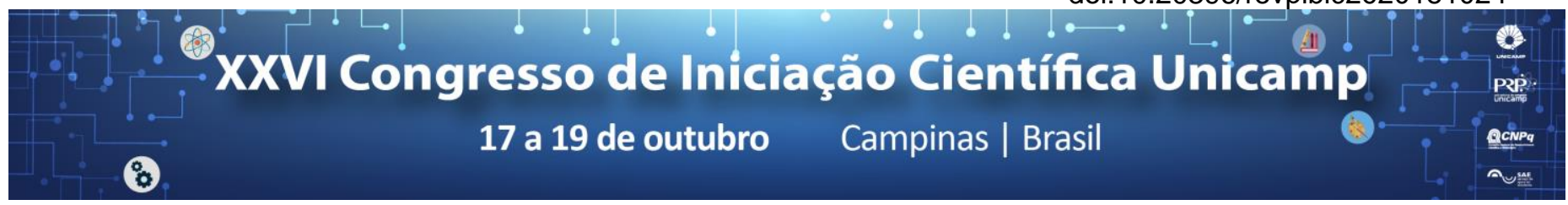

\title{
Effects of supercritical carbon dioxide on the physicochemical properties of apple juice enriched with Brazilian ginseng roots extract
}

\author{
Matheus A. Bargas, Eric Keven Silva, Renata Vardanega, M. Angela A. Meireles
}

\begin{abstract}
The development of non-thermal treatments associated to the formulation of functional products have been a challenge for the food industry. In this sense, the enrichment of apple juice with aqueous extract of Brazilian ginseng (Pfaffia glomerata) followed by the processing of the beverage using supercritical carbon dioxide (SCD) was proposed. The functional beverage was characterized with respect to $\mathrm{pH}$, soluble solids content (SSC), particle size distribution, zeta potential (ZP) and color analysis.
\end{abstract}

Key words: functional beverage, beta-ecdysone, supercritical technology.

\section{Introduction}

The study of non-thermal processes for food stabilization along with the formulation of functional products have been a challenge for the food industry. The enrichment of natural apple juice with aqueous extracts of Brazilian ginseng ( $P$. glomerata), followed by the processing of the beverage with SCD, represents the development of an innovative functional product. Brazilian ginseng is a plant native from Brazil that has a rich composition of bioactive compounds, including betaecdysone and prebiotic carbohydrates such as fructooligosaccharides (FOS) and inulin ${ }^{1}$.

The use of supercritical technology, in particular SCD, for the treatment of food products is an attractive alternative for application in the functional beverages industrialization, as it enables a non-thermal solution for the processing of this type of product. The high-pressure SCD application is an efficient method for inactivating bacteria, viruses, yeasts and enzymatic inactivation ${ }^{2}$.

In this context, the aim of this work was to evaluate the effects of supercritical technology using SCD on the physicochemical properties of a functional beverage, ginseng extract-enriched apple juice. The pressure levels (8 and $21 \mathrm{MPa})$, temperature $\left(40\right.$ and $60{ }^{\circ} \mathrm{C}$ ) and $\mathrm{CO}_{2}$ volume ratio (20 and $50 \%$ ) were evaluated with a fixed process time of 10 minutes.

\section{Results and Discussion}

Table 1 shows the results for $\mathrm{pH}$, soluble solids content (SSC), particle mean diameter $\left(D_{32}\right)$ and zeta potential (ZP). The process conditions did not significantly modify the $\mathrm{pH}$ and SSC.

The PSD had evaluated by $D_{32}$ and showed that an increase in pressure and temperature, combined with a lower proportion of $\mathrm{CO}_{2}$ volume, resulted an increase in $\mathrm{D}_{32}$.

ZP was influenced by the $\mathrm{CO}_{2}$ volume ratio, increasing its value linearly with increases in $\mathrm{CO}_{2}$ volume.

The color analysis had evaluated the parameters $L^{*}$, $\mathrm{C}^{*}$ and $\mathrm{h}^{*}$ and showed that SCD treatment influences the functional beverage, high levels of pressure contributed to an increase in the luminosity of the samples.
Table 1. Physicochemical characterization.

\begin{tabular}{|c|c|c|c|c|c|c|}
\hline $\begin{array}{l}\mathbf{P} \\
\text { (MPa) }\end{array}$ & $\begin{array}{l}\mathrm{T} \\
\left({ }^{\circ} \mathrm{C}\right)\end{array}$ & $\begin{array}{l}\text { V } \\
(\%)\end{array}$ & $\mathrm{pH}$ & $\begin{array}{l}\text { SSC } \\
\text { ('Brix) }\end{array}$ & $\begin{array}{l}D_{32} \\
(\mu \mathrm{m})\end{array}$ & $\mathrm{ZP}(\mathrm{mV})$ \\
\hline \multirow{5}{*}{8} & \multirow{3}{*}{40} & 20 & $\begin{array}{l}4.11 \\
+0.02\end{array}$ & $\begin{array}{l}14.9 \\
+0.1\end{array}$ & $\begin{array}{l}3.45 \\
+0.09\end{array}$ & $\begin{array}{l}-16.83 \pm \\
0.39\end{array}$ \\
\hline & & & 4.10 & 14.7 & 1.42 & $-22.03 \pm$ \\
\hline & & 50 & \pm 0.00 & \pm 0.1 & \pm 0.37 & 0.80 \\
\hline & \multirow{2}{*}{60} & 20 & $\begin{array}{l}4.02 \\
\pm 0.00\end{array}$ & $\begin{array}{l}14.6 \\
\pm 0.1\end{array}$ & $\begin{array}{l}4.65 \\
\pm 0.73\end{array}$ & $\begin{array}{l}-20.53 \pm \\
0.19\end{array}$ \\
\hline & & 50 & $\begin{array}{l}4.02 \\
\pm 0.00\end{array}$ & $\begin{array}{l}14.9 \\
\pm 0.0\end{array}$ & $\begin{array}{l}3.23 \\
\pm 0.72\end{array}$ & $\begin{array}{l}-20.93 \pm \\
0.67\end{array}$ \\
\hline \multirow{5}{*}{21} & \multirow{2}{*}{40} & 20 & $\begin{array}{l}4.12 \\
\pm 0.01\end{array}$ & $\begin{array}{l}14.9 \\
\pm 0.1\end{array}$ & $\begin{array}{l}3.06 \\
\pm 0.31\end{array}$ & $\begin{array}{l}-17.45 \pm \\
1.06\end{array}$ \\
\hline & & 50 & $\begin{array}{l}4.11 \\
\pm 0.01\end{array}$ & $\begin{array}{l}14.7 \\
\pm 0.1\end{array}$ & $\begin{array}{l}3.88 \\
\pm 0.26\end{array}$ & $\begin{array}{l}-24.78 \pm \\
0.25\end{array}$ \\
\hline & \multirow{2}{*}{60} & 20 & $\begin{array}{l}3.96 \\
\pm 0.07\end{array}$ & $\begin{array}{l}14.9 \\
\pm 0.0\end{array}$ & $\begin{array}{l}3.31 \\
\pm 1.55\end{array}$ & $\begin{array}{l}-18.53 \pm \\
3.22\end{array}$ \\
\hline & & 50 & $\begin{array}{l}3.96 \\
\pm 0.08\end{array}$ & $\begin{array}{l}15.0 \\
\pm 0.0\end{array}$ & $\begin{array}{l}3.86 \\
\pm 0.63\end{array}$ & $\begin{array}{l}-24.60 \pm \\
0.99\end{array}$ \\
\hline & Control & & $\begin{array}{l}4.09 \\
\pm 0.08\end{array}$ & $\begin{array}{l}14.8 \\
\pm 0.1\end{array}$ & $\begin{array}{l}4.73 \\
\pm 0.12\end{array}$ & $\begin{array}{l}-24.10 \pm \\
0.14\end{array}$ \\
\hline
\end{tabular}

The results are presented as the mean \pm standard deviation.

\section{Conclusions}

The results obtained have demonstrated that supercritical technology is a promising alternative for the non-thermal processing of functional products, such as the functional apple juice enriched with Brazilian ginseng roots extract, not promoting significant physicochemical alterations on the processed systems.

\section{Acknowledgement}

The authors thank FAPESP (2015/22226-6 and (2017/11641-8), CAPES and CNPq (302423/2015-0) for the financial support.

\footnotetext{
1 Vardanega, R., Santos, D. T., Meireles, M. A. A. Proposal for fractionating Brazilian ginseng extracts: Process intensification approach, Journal of Food Engineering, 196 (2017) 73-80.

${ }^{1}$ Silva, E. K.; Alvarenga, V. O.; Bargas, M. A.; Sant'ana, A. S.; Meireles, M. A. A. Non-thermal microbial inactivation by using supercritical carbon dioxide: Synergic effect of process parameters. The Journal of Supercritical Fluids, 139 (2018) 97-104.
} 